Article

\title{
The Balkans of the Balkans: The Meaning of Autobalkanism in Regional Popular Music
}

\author{
Marija Dumnić Vilotijević $(\mathbb{C}$ \\ Institute of Musicology, Serbian Academy of Sciences and Arts, 11000 Belgrade, Serbia; \\ marijadumnic@yahoo.com
}

Received: 1 April 2020; Accepted: 1 June 2020; Published: 16 June 2020

\begin{abstract}
In this article, I discuss the use of the term "Balkan" in the regional popular music. In this context, Balkan popular music is contemporary popular folk music produced in the countries of the Balkans and intended for the Balkan markets (specifically, the people in the Western Balkans and diaspora communities). After the global success of "Balkan music" in the world music scene, this term influenced the cultures in the Balkans itself; however, interestingly, in the Balkans themselves "Balkan music" does not only refer to the musical characteristics of this genre-namely, it can also be applied music that derives from the genre of the "newly-composed folk music", which is well known in the Western Balkans. The most important legacy of "Balkan" world music is the discourse on Balkan stereotypes, hence this article will reveal new aspects of autobalkanism in music. This research starts from several questions: where is "the Balkans" which is mentioned in these songs actually situated; what is the meaning of the term "Balkan" used for the audience from the Balkans; and, what are musical characteristics of the genre called trepfolk? Special focus will be on the post-Yugoslav market in the twenty-first century, with particular examples in Serbian language (as well as Bosnian and Croatian).
\end{abstract}

Keywords: Balkan; popular folk music; trepfolk; autobalkanism

\section{Introduction}

The term "Balkan", including its derivates, has been the subject of numerous attempts of definition (the most prominent and comprehensive of which is the book: Todorova 1997), as well as debates and critiques (Bakić Hayden 1995; Bjelić and Savić 2002): it can be said that it is a manifold metaphor-of war (the oldest and the most negative one); then, of crossroads, bridges, betweenness, European inner Other/Orient (mostly accepted in theoretical literature); of wildness and pleasure, with derived auxiliaries such as macho men, erotic women, Romas and specific world music genres (stereotypes with positive connotation, mostly used in contemporary tourism and entertainment industries). What is characteristic for all of them is that they are invented as external associations (outside of the Balkans) and that they are consequently internalized in the Balkans. This process of understanding of the Balkans from the Balkan peoples themselves, but as reflection of the external image of the Balkans is called autobalkanism, and it is emphasized when it comes to positive stereotypes, since they are easier to adopt (Dumnić 2012, p. 348). The concept of autobalkanism seems relevant not only because it explains this interesting cultural appropriation, but also because it became a significant marker for Balkan diaspora communities, especially visible in the popular music industry from the 2010s onwards. This article examines what are manifestations of autobalkanism in contemporary regional popular music and provides a typology of their meanings. It also asks a question what can be "autochthonous" self-identification as related to the term "the Balkans" in the region itself in the beginning of the twenty-first century, and how that can be manifested in music-in other words, is it actually possible to 
avoid hitherto established stereotypes in music; moreover, does the term "Balkan" have any meaning if it is not related to the Balkan audiences, and what can be regarded as "Balkan music" today?

For the purpose of this research, "new" media which are relevant for music in the 2010s should be considered. The subject of this analysis is the type of music which is massively popular in the Balkans, according to the millions of views on the YouTube platform. This genre of regional popular folk music is named here as trepfolk (in English: trapfolk; see also: Dragojlo 2019) and it can be defined as an outcome of the evolution of turbofolk/popfolk, whose most recognizable parameters (such as vocal timbre and ornamentation) are influenced by a contemporary local mainstream hip-hop branch which inclines towards dancehall (with distinctive parameters such as particular beats and "auto-tune" effect), and is popular among youth who consume music mainly via streaming platforms. Although YouTube is the main medium of this music scene in Serbia, the analytics of streaming platforms is not the only relevant parameter of popularity. It is questionable whether this music would be so popular according to the criteria of records and tickets sales, airtime and the critics' approval. Still, music reception on YouTube has gained attention in ethnological narratives (Blagojević 2018). Very quickly, the author of this article realized that there exists a genre which is neither named on the regional market, nor analyzed, nor even criticized in detail. This music scene consisting of songwriters, songs and performers, is ignored in the academic discourse and journalism, as it had been the case previously with similar music genres at their outsets (e.g., turbofolk), which were described as kitsch after the initial academic silence they received (Dragićević Šešić 1994; Kronja 2001). The author of this text considers the artistic quality of these music forms as being low, although this is obscured by snazzy production. These songs do not possess complex instrumental parts and harmonies, vocal parts are often poor (both in terms of singing intonation and rap diction), while the lyrical content is mostly devoid of any message apart from glorification of banal consumerism, criminal activities and sexism. Yet, the social relevance and impact of the music taste of youth in the 2010s should not be neglected; these are considered in light of their participation in the construction of Balkan cultural representation.

The aim of this article is to discuss what "the Balkans" means in the Balkans themselves, using the example of popular music made in that area and for the market of former Yugoslavia and its diaspora. Although the Balkans is not the most common main theme in contemporary regional popular music (despite an increased mentioning of the adjective "Balkan" in lyrics, in comparison with popular folk songs from previous decades, the most frequent theme is love), it is analyzed here as an example of musical representation and self-identification of a certain collective in southeastern part of Europe. Part of "the Western Balkans" (specifically, Serbia) is observed here because it has a common music heritage and its popular music market was established in the nineteenth century, which can be traced through various forms of urban folk music genres (Beissinger et al. 2016). Today, commonalities in regional popular music are based to a large extent on language similarities (between Serbian, Croatian and Bosnian, today's languages which were part of Serb-Croatian/Croat-Serbian during the existence of Yugoslavia), but also on following dominant global tendencies in mainstream popular music production, industry and the market.

\section{Regional Popular Music}

Contemporary global popular music of anglophone origins is omnipresent in the region of the Balkans - there are fans of genres such as pop, rock, R\&B, hip-hop, EDM, DIY experimental music practices, etc., and globally popular mainstream performers and their songs are also listened to. Moreover, there are local performers whose style imitates elements contained in music performed by global stars of particular genres-e.g., metro-rhythmical patterns, melodic lines, harmonic progressions, vocal and instrumental timbres, clichés in ornamentation, lyrical themes, choreographies, visual appearance and video directing. However, the regional and narrower, i.e., national markets, have been strongly shaped by local folk music practices and even an "Eastern" (i.e., Ottoman) musical legacy, which characterizes almost all music practices typical for the Balkans. Regional popular music synthetizes various local music practices and it is widely accepted, practiced, transmitted and 
distributed within wider social groups in the region. It can be regarded as folk music, i.e., practiced and distributed among larger group of members of a certain community and different from rural musical folklore and Western popular music (Dumnić 2014, pp. 93-94).

In the Balkans, regional popular music consists of popular folk music practices of particular national origins. Popular folk music is considered here as urban folk music which is produced just like any other popular music genre, contrary to musical folklore-i.e., music of a rural and supposed archaic origin (more in: Dumnić Vilotijević 2019a).

Historically, the development of "Western" popular music in the Balkans can be traced to the ascent of audio technologies, and later also to the influence of video and media in the region-namely, there were local adaptations of Schlager, jazz, R'n'R, etc. (later also including recordings in alternative genres such as punk, which are not in the focus of this article); however, there also rose local forms of mainstream popular music sung in local languages-e.g., zabavna muzika (entertainment music) in former socialist Yugoslavia, an umbrella term for local songs in various styles of dominantly Western popular music provenance. On the other hand, popular folk music had a very intense life since the end of the 19th century. Namely, its popularity grew with the development of mass media (which was also Western influenced), despite academic criticism. Printed sheet music, songbooks, radio and television broadcasting, gramophone records, audio and video cassettes, compact discs and finally digital streaming services contributed to its social preponderance over musical folklore and artistic practices, as well as to an expansion of its production, performance scene and publishing industry. This is a good moment to present a brief history of popular music after World War II. Urban folk music before the War gave rise to post-War genres of novokomponovana narodna muzika (newly-composed folk music) and its opposition starogradska muzika (old urban music), which strongly relied on an urban music heritage from pre-World War I and interwar period (more in: Dumnić Vilotijević 2019b). Urban folk songs consisted of florid and cantabile tunes, with a wide melodic range, double or triple bar measures, simple rhythms (sometimes parlando rubato or aksak), harmonies characterized by basic chord progressions (tonic, subdominant, dominant sphere), diatonic modulations to closely related keys (sometimes with mutations); an accompaniment was simple, but its texture depended on the abilities of the pianist or accordionist, or even the orchestra (most prominent were tamburitza ensembles). Newly-composed folk music (NCFM) was enriched with accordion and fast even rhythms, and it was widely popular in the 1960s and 1970s (more about NCFM in: Vidić Rasmussen 2002). In the 1980s, electronic instruments (synthesizers, electric guitar and bass-guitar) and drum battery, as well as loud sound systems, became regular parts of folk music ensembles, and music videos became very important. This development lead to the evolution of NCFM into turbofolk in the late 1980s, which featured Eurodance rhythms and singing style, and instrumental elements of rock music as another Western influence; all of these styles were grafted onto the NCFM, which also started to incorporate more and more melodic and vocal associations to Oriental music practices. This genre was given a derogatory moniker of turbofolk and subjected to harsh criticism-because of its presumed political background during the 1990s, its associations with war, nationalism and criminality, high commerciality and low quality, as well as vulgarity in both lyrics and videos (Dragićević Šešić 1994; Gordy 1999; Čolović 2000; Kronja 2004; Đurković 2018). ${ }^{1}$ Although the term was not emic, ${ }^{2}$ it definitely became a signifier of popular folk music from the 1990s and an important reference for the genre of trepfolk, which is the subject of this article. There exists a long list of academic publications about turbofolk, but a brief description of this controversial music genre can be summed up as follows: it is a (sub)genre of popular folk music which combined NCFM melodies and lyrical themes, "Oriental" ornamentation,

1 More on all aforementioned genres in: (Dumnić Vilotijević 2019a).

2 "Emic constructs are accounts, descriptions and analyses expressed in terms of the conceptual schemes and categories regarded as meaningful and appropriate by the native members of the culture whose beliefs and behaviors are being studied. (... Etic constructs are accounts, descriptions and analyses expressed in terms of the conceptual schemes and categories regarded as meaningful and appropriate by the community of scientific observers" (Lett 1990, pp. 130-31). 
rock instrumentation and "modern" dance rhythms of the time, and was mainstream at the time of the Yugoslav wars and economic crises in successor states during the 1990s.

How does the history of the 20th-century urban folk music relate to with "Balkan music"? Not at all-except for the fact that it is a pan-Balkan phenomenon, in terms of similar music practices, which implied performances in taverns, networking of musicians, the same types of ensembles and similarities in musical forms, even the same tunes. Namely, "Balkan" at that time was not the buzzword for music industry for the regional market ${ }^{3}$ - "Balkan" as music label was (and it still is) important primarily for exported music. As Karamanić and Unverdorben claim, there are different approaches to Balkan world music and to Balkan turbofolk, considering "whether some particular music is produced and consumed in the core or periphery, and if it is designed for high or lower class taste" (Karamanić and Unverdorben 2019, p. 166). "Balkan music" as a term was known in the USA in the first half of the twentieth century, but its global fascination is of a much later date, precisely the 2000s, when this label began to be used at world music scene to identify music whose essential characteristics are: trumpet accompaniment, emphasized es-tam (fast double) or aksak (7/8, 9/8) rhythm, appearances of the hijaz tetrachord, the timbre of backing vocals typical of the singing manner of the Central Balkans, singing in Slavic or Romany languages. The most prominent performers of this genre are: Goran Bregović, Emir Kusturica, Boban and Marko Marković, Fanfare Ciocarlia, Gogol Bordello, DJ Shantel, Balkan Beat Box etc. (more in: Dumnić Vilotijević 2018, pp. 94-95). It is important to emphasize that this "Balkan music" is a (sub)label within world music, i.e., its main purpose is to musically construct and bring closer associations about authenticity of the region to Western audiences. It contains divergent music content (meaning not only from different locations, but also ranging from "authentic" folklore to hybrid artistic forms and arrangements, with all their inner diversities). In other words, the connection of music and place is constructed in order to mark one particular genre (consisting of various forms) in the global (but first of all Western) music industry. In Serbia, world music had a local incarnation in the so-called ethno music genre, which proclaimed the preservation of local heritage and opposed turbofolk both aesthetically and ideologically cf. (Nenić 2009). The protagonists of the ethno music scene avoided the adjective "Serbian" in favor of "Balkan" in their names (e.g., Balkanika, Balkanopolis, Balkan Salsa Band), as well as the names of their projects (Medić 2014, p. 112). It should be noted that the previously mentioned stereotypes about the Balkans and Balkan music are internalized in the Balkans, so there are examples of autobalkanism in world music, the most prominent example of which is the song "Ovo je Balkan" (This is the Balkans) by Goran Bregović and Marina Tucaković, originally written for the Eurovision Song Contest in 2010 (more in: Dumnić 2012).

This brief history is important in order to explain the extension of turbofolk which appeared in the 2000s-named as popfolk, because it combines popular folk music (where ornamentation styles are the most distinguished "folk" marker) with current pop music trends and arrangements (mostly borrowed from R\&B and pop-rock, especially in terms of vocal melody and orchestration, which implies live instrumental performances). It can be even argued that NCFM, turbofolk, popfolk (and trepfolk) have always been heterogeneous genres and that there are overlaps among some of them during the recording careers of the main protagonists of this mainstream regional popular music. Moreover, they have coexisted simultaneously, so apart from the genres that are here representative of the mainstream popular folk music of certain decades, these labels (NCFM, turbofolk, popfolk, trepfolk) can also refer to the identification of certain stylistic tendencies. While autobalkanism overwhelmed regional world music scene in the 2000s, popfolk brought along "modernization" and tools for music production, which became necessary for the main regional popular folk music of the 2010s, which is emphatically—autobalkanistic. ${ }^{4}$

3 According to the analysis of song lyrics conducted in 2009, turbofolk was not the main genre where the word "Balkan" appeared, it was hip-hop (Cvitanović 2009, pp. 323, 327).

4 It must be mentioned that popfolk is still a vital genre in the popular music scene all over the Balkans. 


\section{Trepfolk as Balkan Popular Music}

In the 2010s regional popular music was quite heterogeneous and comprised genres such as pop, rock, hip-hop, popfolk and others, with interesting crossovers. In terms of performing mainstream music and its media distribution, TV formats such as talent competitions and reality shows became a base for promotion of new performers, who pay special attention to marketing in tabloids, visual representation and social media, and promote their songs at streaming platforms (such as Deezer, iTunes, Spotify, and especially on YouTube). Until the 2010s, radio and television were the most important channels for broadcasting regional popular folk music. Today television still plays an important role (e.g., Radio-Television of Serbia, Pink, Grand, KCN, DM Sat), especially channels have satellite program or web presentations (which are crucial for the diaspora audiences) and if they are also involved with music production. Such an environment gave rise to a genre which has been popular among young audiences all over the Western Balkans and their diaspora-trepfolk. As was the case with its predecessors, trepfolk sounds technically progressive (i.e., "Western", "modern"), as if it attempts to leave behind the musical heritage of "folk", "old" and "Orient", however it must preserve some of its remnants in order to be commercially viable at that market. Trepfolk is rooted in the dizel (diesel) subculture of the 1990s, ${ }^{5}$ both in terms of its development from turbofolk and from one part of the local hip-hop scene, and all that is glorified in its "retro" musical and visual aesthetics (more about dizel movement in Serbian hip-hop in: Musić and Vukčević 2019). It is not praised among the intellectual elite (either of left or right provenience), but it is popular all over the post-Yugoslav space, even in the countries of the European Union-namely Croatia and Slovenia, where one segment of this scene originates from, despite official aspirations to avoid associations with the Balkans and regional popular music (from turbofolk onwards). Also, trepfolk is popular in countries with large communities of emigrants from South Eastern Europe, such as Austria, Germany, Sweden and Switzerland. ${ }^{6}$ Its omnipresence (also perceivable on both radio and television) is not rooted in some political project or belief in some artistic value-it is absolutely commercially oriented, aiming towards obtaining large profits from sold products (more in: Nikačević 2019). Based on its massive acceptance and actual continuation of its production, it can be presumed that it will be a vital genre in the 2020s as well.

Trap is derived from hip-hop and its producers are nowadays actually key figures in profiling this genre-as one of them told, the formula for this music is "melos (this refers to folk, M.D.V), electro, hip-hop and Caribbean rhythms" (Relja, in: Nikačević 2019). Hip-hop influenced turbofolk in the 1990s, and a reverse process unfolded in the 2010s trap music (also called "estrada-rap collaboration", which was emically perceived as a bridge between mainstream and alternative popular culture: cf. Nikačević 2018), so this symbiosis was expected. Trap in the Balkans is actually a result of global musical evolution of hip-hop with its usual poetic themes; however, a local characteristic is its glorification of the legacy of the turbulent 1990s, which implies trap's lack of moral and aesthetic norms and shallowness, and also a stylistic omnivorism of this generation (they are in their twenties and thirties) (more in: Đorđević 2019). On the other hand, trepfolk contains "folk" music, i.e., the melodic part sung by a star of turbofolk or popfolk. ${ }^{7}$ This actually demonstrates patinization of the 1990s turbofolk as an acceptable reference after decades, as well as consequences of reviving an aesthetically and poetically problematic model. Namely, turbofolk evolved both technically and stylistically, and trepfolk emanated from it. The main characteristics such as vocal timbre, melismas, poetical themes of the

5 "Young people-connected with the aforementioned new type of urban music, street speculating, gyms and body-building, tempered attitude, fast cars and expensive workout gear, and who imitate young gangsters ( ... ) -very quickly were called dizelaši by the local media" (Musić and Vukčević 2019, p. 181).

6 There is even a song Balkan Mädchen [Balkan Girl], sung in German by an Austrian musician of Serbian origin called MC Yankoo (2018) (https://www.youtube.com/watch?v=EFIAGtwwPQ4, accessed on 4 May 2020).

7 Another interesting revitalization of turbofolk, but with alternative music forms, is the genre of turbotronik—cf. (Rašić 2018; Banić Grubišić and Kulenović 2019; Kulenović and Grubišić 2019). 
songs and even performers were taken from turbofolk, but there is also an explicit fascination with the turbofolk legacy. An example is the song Samo jako [Only Strongly], ${ }^{8}$ with a prominent turbofolk singer Stoja, and there is a hook from the song that she released in 2000 (Samo [Only]) treated as a leitmotif. This song also participates in an autobalkanistic stereotypization, describing the Balkans as a place of criminal and turbofolk. ${ }^{9}$

The main labels of this scene, characterized by high production levels, are: Bassivity Digital, IDJ Videos, Balkaton and Imperia - all of them are focused on digital publishing. The main active performers in trap parts of the songs are: Rasta, Coby (also the producers), Relja, Mimi Mercedez, Jala Brat, Buba Corelli, Connect, Senidah; there are also performers who are in charge of folk parts of songs, such as: Dara Bubamara, Dado Polumenta etc. (mainly singers signed to Grand, the label oriented towards popfolk), or singers who combine these two styles; guest-performers such as MC (e.g., Stojan) and/or DJ (e.g., Shone). ${ }^{10}$ The success of this genre is initialized with trending when the song appears and its reception is measured with views, likes (and the absence of dislikes), comments, subscribes, follows and shares on YouTube and social media; at the same time, the purpose of this mass production is to promote performers in order to sell tickets for their live performances, especially in nightclubs abroad. Particular songs are no longer perceived as musical pieces-as we can conclude from reading the credits, these songs are made of lyrics and "music" (i.e., vocal with an accompanying electronic track, often without any acoustic or electric instrumental performances), but their other constitutive parts are choreography and dance, as well as video recording, directing and editing; even hairstyle and makeup are perceived as important parts of the whole piece, i.e., music video. This music lives not only in performances of persons who recorded it, but also in remixes. It is interesting that, for the first time, popular folk song does not depend on its singer and live performance, but instead on its producer (who comes from an urban genre such as hip-hop) and media distribution.

What follows is an overview of some of trepfolk's basic musical characteristics. The most distinctive feature of this genre is the vocal part, which is strongly colored by an easily detectable autotune effect (digital pitch-editing). The use of autotune is not only about the authenticity of the voice, the performer's singing ability and fixing errors in intonation-it is the symbol of modern technology used in production (i.e., various plug-ins) and an aesthetic imperative in a section, especially the rap part of the song. ${ }^{11}$ Except this, a trap vocal can be processed in numerous ways-to sound like a "telephone" or "robot" voice, with added delay, reverb, vibrato or equalization. Musically, the trap part of this genre contains recitative and melodic parts. The folk vocal (in critical accounts it may be known under other names - in Serbian: narodnjak, in Croatian: cajka) simulates popular music of the entire Balkan region (known not only in former Yugoslav countries, but also in Albania, Bulgaria, Greece, Romania and Turkey). It has a specific timbre and prominent melisma within its more developed melody, which is usually described as Oriental heritage. Also, the vibrato in vocal cadenza, emphasized melisma called emically triler (trill), even an effect of drone accompaniment for the main vocal can be produced electronically, so there is a stylistic distinction in performance between processed vocal of trap and "authentic" singing of folk soloist.

The highlighted vocal and effects are layered over prerecorded matrix, which basically contains sequenced and sampled backbeats in ostinato. It is actually the harmonic-methro-rhythmical foundation

8 Performed by Relja, Coby and Stoja (2017) (https://www.youtube.com/watch?v=95zxduB-WrI, accessed on 5 March 2020).

9 This generation of hip-hop performers became aware of turbofolk as part of their childhood culture, which sometimes connotes irony with regards to their interpretation of turbofolk; however, it is interesting that these performers avoid any criticism of turbofolk-instead, they glorify that phenomenon. Cf. Turbofolk me je naterao [Turbofolk Made Me] performed by Polo Čare and Mimi Mercedez (2015) (https://www.youtube.com/watch?v=EL-Y5SPLSeI, accessed on 5 March 2020).

10 Generally there are no ensembles in this genre-it is based on a collaboration between a particular producer (who creates music), one or more trap (or hip-hop) performers (they may be organized in groups in their basic genre), and a singer of turbofolk or popfolk provenience; there are also examples of a soloist who is not instrumentally accompanied (s/he sings over an electronic track). The impression of collectivity is aided by dance accompaniment.

11 More on autotune in popular music in: (Diaz 2009; Reynolds 2018). 
of the song and, like other electronic dance music product, it is manipulated with various digital tools in the studio (more in: Wang 2012). Fast double beats in this music are not based only in hip-hop: their styles and patterns originate from house, but also from popular Afro- and Latino-Caribbean genres such as reggaeton, merengue etc. ${ }^{12}$ Actually, stereotypes about "Latino" culture are not only evoked through these rhythms and video spots which reference tropical destinations and dances, but also in trepfolk lyrics-e.g., in the use of words such as "bebe", singing about the Balkans as "Latino Europe", the place with sensual women, where wild parties and criminal flourish. ${ }^{13}$ Due to all these characteristics, this genre has plenty of conceptual and stylistic similarities with dancehall.

There are other distinctive elements of trepfolk. References to regional popular folk music include highlighted sounds of instruments such as accordion, trumpet, saxophone or zurla. One also finds čoček rhythmic pattern and rumba-rhythm, which is a distinctive mark for reggaeton too (boom-chaboomchick-boom-chaboom-chick, as described in Manuel and Largey (2016, p. 113)). These elements which provide trepfolk with associations on the Balkans are found in various folk music traditions all over the region, and one of most prominent is Romani.

In terms of lyrics, trepfolk deals with themes such as love (with sub-themes such as erotic women, macho men etc.), parties, drug abuse and criminal, materialism (cash is often mentioned, and one also finds enumerations of expensive clothing or car brands), fast lifestyle, nostalgia for home-all from everyday life, as they perceive it. The topos of the Balkans is present in all of them.

\section{Stereotypes about the Balkans in Trepfolk}

First of all, "the Balkans" in trepfolk has an implied meaning for its audience-the place of origin for the people from the former Yugoslavia (and, it might be presumed, Bulgaria as well). ${ }^{14}$ It is interesting that neither particular national, nor Yugoslav identities are emphasized in these songs, and ethnic hatred is bypassed-actually, these songs avoid nationalism or any other larger concept or value, except for consumerism. Transcending national borders with turbofolk/popfolk (known not only through the popularity of several performers all over the Balkans, but also through the existence of similar tunes sung in various languages) continued with trepfolk, and its pan-Balkan reception is known in practice. A very interesting case is the hidden popularity of turbofolk in Croatia (Baker 2007; Gotthardi-Pavlovsky 2014), and nowadays of trepfolk (Rafaneli 2019; Milevoj 2018), but also a renewed popularity of some NCFM stars as a symptom of Yugonostalgia (Hofman 2012). All songs are in Serbian, Bosnian or Croatian language, so it was logical that they would be profitable in a market larger than the narrowly-national (although not all people who understand these languages consume this musical genre).

Although global popular music and Western stereotypes about the Balkans served as models for internalizations, it is curious to understand what "the Balkans" means in the songs which are made in the Balkans, represent music of the Balkans, were intended for the Balkans and even demonstrate collaborations among the people from the Balkans with each other (i.e., the mix various ethnic identities from the Balkans). On the other hand, this music is purposely made to be exported to the diaspora, i.e., "Our People Out-of-Balkans". ${ }^{15}$ In other words, the term "the Balkans" is again used in the area which is not the Balkans, but it has another value-it is for people who are familiar with the area, who are in

12 More on Caribbean musics and their global influence in: (Manuel and Largey 2016).

13 Cf. Latino Evropa-performed by Relja (2018) (https://www.youtube.com/watch?v=cq8Lt0vRVRI, accessed on 5 March 2020); Balkan fiesta-performed by Maja Marijana ft. MC Miloš (2014) (https://www.youtube.com/watch?v=vdzI8o-3B7w, accessed on 5 March 2020).

14 For example, in the song Srce balkansko [Balkan Heart] performed by Ado \& Dino ft. DJ Boki Kopenhagen (2013) (https://www.youtube.com/watch? v=wbdP0hBeyC4, accessed on 5 March 2020), the following countries are named: "Bosnia, Serbia, Albania, Slovenia, Montenegro, Croatia, Macedonia, Bulgaria", with proclaimed unity.

15 It is even sung in one song by naming particular countries: Germany, Denmark, Switzerland Cf. Luda balkanska [Balkan Crazy Woman] performed by Milena Ćeranić ft. DJ Kizami \& DJ Marchez (2014) (https://www.youtube.com/watch?v=969vEWz--0Q, accessed on 5 March 2020). In some songs, this market can be referred to as "cela Evropa" ("whole Europe"). 
a virtual or real contact with their homeland, hence the term connotes a different music style and new stereotypes. This huge market needed specific music from the countries of the audience's origin, in local languages, with elements of familiar regional popular music (turbofolk/popfolk), but modernized with global trends such as trap and electronic tracks. At the same time, performers expanded possibilities for earning profit from live performances. "The Balkans" here means the longing of migrants for their faraway home, i.e., restorative nostalgia, as Svetlana Boym called it (Boym 2001, p. XVIII). Trepfolk genre actually demonstrates musical hybridity in multicultural settings such as the diaspora. ${ }^{16}$ It is interesting that autobalkanism, which is contained in trepfolk, carries the continuation of the "escapist, utopian Yugonostalgia" ("a commercial phenomenon that celebrates and exploits the longing for an idyllic Yugoslav past", as defined in: Volčič 2007, p. 28). Namely, the youth of Balkan origins living abroad is connected through trepfolk, regardless of their homeland and recent wars. This new generation seems not burdened by the notion of Yugoslavia, so this autobalkanistic tendency in music may be interpreted as nostalgia of contemporary youth for a distant and collective home with (pseudo-)positive connotations, i.e., the Balkans.

Although the trepfolk genre is not made for an audience who is unfamiliar with the Balkans, it uses and internalizes several typical stereotypes about the Balkans (both positive and negative, with derived adjectives). ${ }^{17}$ It is interesting that this music is neither about war, wild savages (as it was case with the most frequent stereotypes about the Balkans in foreign popular culture, later employed in world music), nor about a typical Balkan kafana (tavern), ${ }^{18}$ soul, ${ }^{19}$ provincial men ${ }^{20}$ (as was the case in turbofolk and popfolk), crossroads and European "inner Other". ${ }^{21}$ At the same time, autobalkanization may be observed as a process of finding the new collective identity in the Western Balkans which tends to overcome negative consequences of recent wars in Yugoslavia, with connective potential (Cvetanović 2019, p. 147). Autostereotypical metaphors in lyrics about "the Balkans" include: macho men, erotic and strong women, war, being proud of their origin, party and criminals. In the following examples of music videos in Serbian language in which "Balkan" is the theme in the title, various aspects of its use are highlighted.

\subsection{Balkan as Distant Homeland}

Verses of the song Ja volim Balkan ${ }^{22}$ [I Love the Balkans] reveal an explicit idea of performers to be invited to European nightclubs frequented by the Balkan diaspora (MC is singing with autotune: Klubovi me čekaju, Evropa zove [Clubs are waiting for me, Europe is calling]). With processed vocal line and autotuned voice MC is singing in English Throw it up for Balkan, baby, that's the new sound, accompanied by house track with prominent bass-revealing an obvious aspiration towards the proclaimed "modern" sound for the young (especially European) audience. Popfolk singer sings the chorus over a new beat: Na koži Balkan istetoviran, / u srcu majka rođena, / vuče me nostalgija, / naši ljudi i muzika [Balkan is tattooed on my skin, / my mother is in my heart, / nostalgia pulls me, / so do our people and music] (with the last word looped and repeated). It can be noted that "the Balkans" is the homeland for the diaspora community, with music (such as this one) which evokes nostalgia. After the popfolk singer's part, there is an instrumental interludium on the accordion (with an embellished melody), which is a very direct reference to folk music in the countries of the former Yugoslavia. The music video showcases expensive

16 More on hybridity related to music in the diaspora in Ramnarine (2007).

17 It must be said that the topic "the Balkans" is also present in other genres of regional popular music.

18 E.g., Kafana na Balkanu [Tavern in the Balkans]—performed by Aca Lukas (1998), and Funky G (2008), Balkan-performed by Seka Aleksić (2004). This stereotype is still present in popfolk.

19 E.g., Balkanska duša [Balkan Soul]-performed by Zoran Kalezić (2016).

20 E.g., Balkanac [Balkan Man]—performed by Luna (2005), and Đani (2007).

21 In the 2010s, autobalkanism also existed in popfolk, e.g., Luda glava balkanska [Crazy Balkan Head]—performed by Aca Lukas and Marija Šerifović (2010), and Indira Radić (2015).

22 Performed by Dado Polumenta ft. MC Yankoo, DJ Mlađa and MC Stojan (2011) (https://www.youtube.com/watch?v= OOLio12duC8, accessed on 5 March 2020). 
fast cars, pretty girls and a cheerful European nightclub (with the main marker of its foreignness being Afro-American guests).

\subsection{Balkan as Hospitable Domestic Place}

Balkan is not just (imaginary) homeland for the diaspora, it is at the same time the symbol of domestic hospitality, not just for the diaspora, but also for the people who live in the region. Majka balkanska ${ }^{23}$ [Balkan Mother] is an example where typical Balkan offers are listed in the parts of the male MC and folk singer: food, alcoholic drinks (e.g., rakia), party, hedonism and care for their countryman; moreover, the accompanying music video depicts the countryside. It is interesting that this example combines house track, rap verses and a chorus in ethno music style. Namely, a female singer in the folk costume sings the chorus based on the melody of a folk song from Gora (Kosovo and Metohija) Vrbice, vrbo zelena, with associations on traditional rural folk music timbre and typical exclamations at the end of the verse. It is interesting that this chorus (consisting of two strophes) is proclaiming one mother of the Balkans, without national divisions: Mene je majka rodila, / majka rodila, majka balkanska, / ovde u zemlji dedova. / Ovde u zemlji dedova, / majka rodila, majka balkanska, balkanske pesme pevala [Mother gave birth to me, / mother gave birth to me, Balkan mother, / in the grandparents' land. / Here in the grandparents' land, / mother gave birth to me, Balkan mother, / she sang to me Balkan songs].

\subsection{Balkan as a Place of Beautiful and Seductive Women}

Lepota balkanska ${ }^{24}$ [Balkan Beauty] is in the same musical style (house) as Ja volim Balkan, with a rap part for the MC (there are also verses in English) and the singing part for a popfolk singer who also performs the chorus. The theme is party in a nightclub (also noted in music video and dance), with drinking and seductive dance, with an emphasized mention of "Balkan rhythm", as well as an accordion and folk music. However, the main reference of the song is "Balkan beauty", i.e., beautiful and seductive women who live or have their origin in the region. ${ }^{25}$ This has been a common stereotype about the Balkans in popular culture for a long time and it is present in numerous songs.

\subsection{Balkan as a Place of Strong Women}

The previous stereotype is expanded with representations of women from the Balkans as being strong. For example, the song Balkanka ${ }^{26}$ [Balkan Woman] is about women from the Balkans who are unique in their ability to handle every emotion and social role. The first part of the chorus (highlighted by a lack of bass) is sung by a female popfolk singer: Balkanka, nesrećna i lepa, / Balkanka, i grešna $i$ verna, / Balkanka, nigde takve nema, / twoja Balkanka [Balkan woman, sad and pretty, / Balkan woman, both sinful and faithful, / There is no woman such as Balkan woman, / your Balkan woman]. The processed trap male voice (over the beat with an emphasized bass) sings about his pride to be the only "owner" of the "Balkan woman" in the nightclub. On the other hand, the song Žena sa Balkana ${ }^{27}$ [Woman from the Balkans] is an example of a different trap style, which is a consequence of more complex lyrics, in comparison to the previous song. A turbofolk singer Stoja, recognizable for her voluminous nasal alto and "Oriental" ornamentation, performs choruses, so this duet depicts the clash of hip-hop and turbofolk. The collaboration of two women (the singer and young rapper Mimi Mercedez) and their

23 Performed by Đomla KS, DJ Dyx ft. Ćira and Zorana Bantić (2013) (https://www.youtube.com/watch?v=7-HBIf0zy5U, accessed on 5 March 2020).

24 Performed by DJ Denial X and Sha ft. Mia Borisavljević (2012) (https://www.youtube.com/watch?v=BiPOVLEYZ_g, accessed on 5 March 2020).

25 The same plot and similar music style are also found in less popular songs named Girl from the Balkans: Cura sa Balkana, performed by TrikFX Official (2014) (https://www.youtube.com/watch? v=ztXsGBUNNNc, accessed on 5 March 2020); Djevojka sa Balkana, performed by DJ SNS ft. Semko (2013) (https://www.youtube.com/watch?v=I4HkezStWl4, accessed on 5 March 2020).

26 Performed by Ljupka Stević ft. MC Stojan (2017) (https://www.youtube.com/watch?v=kTvOtgRp2a8, accessed on 5 March 2020).

27 Performed by Stoja ft. Mimi Mercedez (2019) (https://www.youtube.com/watch?v=tU1FihRxv9A, accessed on 5 March 2020). 
proclamation of sisterhood, as well as the depiction of strong and independent women, is in accordance with a feminist attitude inscribed to this "new" Balkans, expressed in the lyrics: Ma biće dana, a biće $i$ para, / a nigde žena kao sa Balkana, / da l' je do gena il' do vaspitanja, / njena je zadnja, ona caruje! [There will be time and money, / but nowhere women such as those from the Balkans, / whether it is due to her genes or education, / but she has the last word, she reigns!].

\subsection{Balkan as Criminal Place}

The metaphor of war (typical of the 1990s turbofolk) is replaced with the metaphor of the Balkans as rife in criminality. For example, that is the discourse of the song Made in Balkan ${ }^{28}$, with lyrics about drugs, criminals and prostitutes in the Balkans; also, the song Krvavi Balkan [Bloody Balkan] ${ }^{29}$ features singing about criminal executions. These songs are both variants of the trap style, while the second one has a more complex instrumental track, hip-hop verses, sung chorus processed with autotune, drone and echo, as well as the music video which shows scenes of shooting and arrests. The song Balkan ${ }^{30}$ musically synthetizes trap in verses (characterized by specific diction and beat which can be found in reggaeton) over the track, with popfolk in the chorus. It is interesting that the song has an introduction played on the bagpipes and female singers who sing the exclamation $(j)_{o j !}$ in the rural folk-singing style, as well as the sound of the brass orchestra in the chorus; all of these evoke the image of the "traditional" Balkans. The lyrics contain "name-dropping" of terms related to luxurious life, money and criminality with the conclusion To je Balkan [That's the Balkans].

"The Balkans" in trepfolk is musically represented by a merger of the turbofolk/popfolk legacy and stereotypes which are common in the Balkans. The purpose of the frequent appearance of "the Balkans" in these songs is to open the diaspora market for contemporary non-turbofolk/popfolk performers, and to modernize regional popular folk music in order to attract younger audiences.

\section{Conclusions}

This paper demonstrated the evolution of stereotypes about the Balkans, and especially of their internalization in contemporary popular music. "The Balkans" produced in the Balkans and for "the Balkan people" (both in the Balkans and outside of the Balkans) nowadays connotes the homeland for the inhabitants of the former Yugoslav space, especially those who migrated to Western European countries; the commercial purpose of this label is to attract that audience to gather in nightclubs. Trepfolk is "Balkan music" of the 2010s; it sings about several autostereotypes about the Balkans, combines an imitation of global mainstream popular music with local practices of popular folk music and it is widespread all over the region and beyond. Trepfolk is a newly-established regional popular music genre from the 2010s, which is massively consumed in the market of the countries of the former Yugoslavia and their European diaspora communities. As a combination of Western-like trap (strongly influenced by Jamaican dancehall) and domestic popular music known since the 1990s as turbofolk/popfolk, it depicts the present-time consumerism in its lyrics. All current stereotypes about the Balkans demonstrate the change of the Balkanistic paradigm in favor of the perspective from the Balkans-this "Balkans" that they sing and rap about is simultaneously their homeland, a hospitable place with beautiful and strong women, but also the place where criminal flourishes. It is interesting that in trepfolk music the stereotypes about the Balkans as place of wars and macho men are not internalized-it was the earlier Balkanistic representations from outside of the Balkans that described the region primarily with negative connotations. It is noticeable that the previous (auto)balkanistic paradigm in music emphasized the rural Balkan folk music features (just like in world music), while the new autobalkanism described

28 Performed by Relja (2019) (https://www.youtube.com/watch?v=GXt2pUJyLbU, accessed on 5 March 2020).

29 Performed by THCF and Coby (2017) (https://www.youtube.com/watch?v=eKT1SYR0z3E, accessed on 5 March 2020).

30 Performed by Rasta, Dado Polumenta and Žuti (2015) (https://www.youtube.com/watch?v=fs9XYB8LKII, accessed on 5 March 2020). 
above aims to communicate with the "modern" Balkans, a relatively peaceful and fun place to be, overwhelmed with trepfolk. Musically, there are no completely new symbols of the Balkans (although there is new genre associated with autobalkanism) - the music analyzed in this article contains the elements known since the 1990s to which trepfolk gave a new significance. Also, the example of trepfolk demonstrates that the term "Balkan" continues to target the audience outside of the region-in this case, it is designed for diaspora communities. Hence, the concept of autobalkanism was relevant to explain how the imported stereotypes developed in the Balkans and how they are used for a new representative music genre.

Funding: This paper was written as a part of the project Serbian Musical Identities within Local and Global Frameworks: Traditions, Changes, Challenges (ON 177004), funded by the Ministry of Education, Science and Technological Development of the Republic of Serbia.

Conflicts of Interest: The author declares no conflict of interest. The funder had no role in the design of the study; in the collection, analyses or interpretation of data; in the writing of the manuscript, or in the decision to publish the results.

\section{References}

Baker, Catherine. 2007. The Concept of Turbofolk in Croatia: Inclusion/Exclusion in the Construction of National Musical Identity. In Nation in Formation: Inclusion and Exclusion in Central and Eastern Europe. Edited by Catherine Baker, Christopher Gerry, Barbara Madaj, Liz Mellish and Jana Nahodilová. London: School of Slavonic and East European Studies Publications.

Bakić Hayden, Milica. 1995. Nesting Orientalisms: The Case of former Yugoslavia. Slavic Review 54: 917-31. [CrossRef]

Banić Grubišić, Ana, and Nina Kulenović. 2019. Turbotronik-Na granici između lokalne muzičke scene i žanra u nastajanju. Etno-antropološki problemi 14: 23-46. [CrossRef]

Beissinger, Margaret, Speranţa Rădulescu, and Anca Giurchescu, eds. 2016. Manele in Romania: Cultural Expression and Social Meaning in Balkan Popular Music. London: Rowman \& Littlefield.

Bjelić, Dušan, and Obrad Savić, eds. 2002. Balkan as Metaphor: Between Globalization and Fragmentation. Cambridge: Massachusetts Institute of Technology.

Blagojević, Gordana. 2018. Turbo-folk i etnicitet u ogledalu percepcije korisnika jutjuba. Glasnik Etnografskog Instituta 60: 155-70.

Boym, Svetlana. 2001. The Future of Nostalgia. New York: Basic Books.

Čolović, Ivan. 2000. Divlja Književnost: Etnolingvističko Proučavanje Paraliterature. Beograd: Biblioteka XX vek.

Cvetanović, Dragana. 2019. Yugospotting u regionalnom hip-hopu. Kultura-Časopis za Teoriju i Sociologiju Kulture I Kulturnu Politiku 162: 143-65.

Cvitanović, Marin. 2009. (Re)konstrukcija balkanskih identiteta kroz popularnu glazbu. Migracijske i Etničke Teme 25: 317-35.

Diaz, Joe. 2009. The Fate of Auto-Tune. Available online: https:/ocw.mit.edu/courses/music-and-theater-arts/21m380-music-and-technology-contemporary-history-and-aesthetics-fall-2009/projects/MIT21M_380F09_proj_ mtech_3.pdf (accessed on 5 March 2020).

Đorđević, Dragan. 2019. Oktobarska revolucija trećeg talasa. Kultura-Časopis za Teoriju i Sociologiju Kulture I Kulturnu Politiku 162: 198-223.

Dragićević Šešić, Milena. 1994. Neofolk Kultura: Publika i Njene Zvezde. Sremski Karlovci: Izdavačka knjižarnica Zorana Stojanovića.

Dragojlo, Saša. 2019. Trep cajke: Kapitalistički realizam. Bilten-Regionalni Portal. Available online: https: //www.bilten.org/?p=28232 (accessed on 5 February 2020).

Dumnić, Marija. 2012. This Is the Balkans: Constructing Positive Stereotypes about the Balkans and Autobalkanism. In Musical Practices in the Balkans: Ethnomusicological Perspectives-Proceedings of the International Conference Held from November 23 to 25, 2011. Edited by Dejan Despić, Jelena Jovanović and Danka Lajić Mihajlović. Belgrade: Serbian Academy of Sciences and Arts: Institute of Musicology-Department of Fine Arts and Music, pp. 345-56.

Dumnić, Marija. 2014. Doprinos Studija Performansa Izučavanju Regionalne Popularne Muzike: “Tamburica Fest" kao Izvođenje. Etnološko-Antropološke Sveske 23: 93-104. 
Dumnić Vilotijević, Marija. 2018. Contemporary Urban Folk Music in the Balkans: Possibilities for Regional Music History. Muzikologija-Musicology 25: 91-101. [CrossRef]

Dumnić Vilotijević, Marija. 2019a. Urban Folk Music and Cultural Influences: Labels for Narodna Muzika [Folk Music] in Serbia in the Twentieth Century. In Contemporary Popular Music Studies: Proceedings from the International Association for the Study of Popular Music_Kassel 2017. Edited by Marija Dumnić Vilotijević and Ivana Medić. Wiesbaden: Springer, pp. 39-50.

Dumnić Vilotijević, Marija. 2019b. Zvuci Nostalgije: Istorija Starogradske Muzike u Srbiji. Beograd: Čigoja štampaMuzikološki institut SANU.

Đurković, Miša. 2018. Ideological and Political Conflict about Popular Music in Serbia. Synaxa 2-3: 115-24.

Gordy, Eric. 1999. The Culture of Power in Serbia: Nationalism and the Destruction of Alternatives. University Park: Pensilvania State University Press.

Gotthardi-Pavlovsky, Aleksej. 2014. Narodnjaci i Turbofolk u Hrvatskoj: Zašto ih (ne) Volimo? Zagreb: Ljevak.

Hofman, Ana. 2012. Lepa Brena: Repolitization of Musical Memories on Yugoslavia. Glasnik Etnografskog Instituta 60: 21-32. [CrossRef]

Karamanić, Slobodan, and Manuela Unverdorben. 2019. Balkan High, Balkan Low: Pop-Music Production between Hybridity and Class Struggle. In Eastern European Popular Music in a Transnational Context: Beyond the Borders. Edited by Ewa Mazierska and Zsolt Győri. Cham: Palgrave European Film and Media Studies, pp. 155-70.

Kronja, Ivana. 2001. Smrtonosni Sjaj: Masovna Psihologija i Estetika Turbo-Folka. Beograd: Tehnokratia.

Kronja, Ivana. 2004. Turbo Folk and Dance Music in 1990s Serbia: Media, Ideology and the Production of Spectacle. The Anthropology of East Europe Review 22: 103-14.

Kulenović, Nina, and Ana Banić Grubišić. 2019. Cepaće se neki narodnjaci: Nova čitanja turbo-folka. Etnološko-Antropološki Zbornik 14: 47-78. [CrossRef]

Lett, James. 1990. Emics and Etics: Notes on the Epistemology of Anthropology. In Emics and Etics: The Insider/Outsider Debate. Edited by Thomas Headland, Kenneth Pike and Marvin Harris. Newbury Park, London and Delhi: SAGE Publications Inc., pp. 127-42.

Manuel, Peter, and Michael Largey. 2016. Caribbean Music from Rumba to Reggae, 3rd ed. Philadelphia, Rome and Tokyo: Temple University Press.

Medić, Ivana. 2014. Arhai's Balkan Folktronica: Serbian Ethno Music Reimagined for British Market. Muzikologija-Musicology 16: 105-27. [CrossRef]

Milevoj, Matea. 2018. Otišli smo na trap cajke: Što stoji iza novog glazbenog vala koji spaja hip-hop i turbofolk? Muzika.hr. Available online: https://www.muzika.hr/trap-cajke-hype-beats/ (accessed on 5 March 2020).

Musić, Goran, and Predrag Vukčević. 2019. Diesel Power: Hip-hop u Srbiji od zadovoljstva povlašćenih do masovne omladinske kulture. Kultura-Časopis za Teoriju i Sociologiju Kulture i Kulturnu Politiku 162: 166-97. [CrossRef]

Nenić, Iva. 2009. Popkulturalni povratak tradicije (World da, ali Turbo?). In Istorija Umetnosti u Srbiji XX veka (1): Radikalne Umetničke Prakse 1913-2008. Edited by Miško Šuvaković. Beograd: Orion Art, pp. 907-16.

Nikačević, Galeb. 2018. Relja i Coby-Bassivity: 20 Godina Borbe za Mesto pod Suncem. Vice. Available online: https://www.vice.com/rs/article/vbj4jb/relja-i-coby-bassivity-dvadeset-godina-borbe-za-mesto-podsuncem (accessed on 5 March 2020).

Nikačević, Galeb. 2019. Rasta i Coby: Tvorci Nove Srpske Muzike. Vice Serbia Documentaries. Available online: https://video.vice.com/rs/video/rep-narodnjaci/5c26029ebe40771d454ba996 (accessed on 5 March 2020).

Rafaneli, Karlo. 2019. Gdje Mediteran ljubi cajke. Arteist-Prvo Slovo Kulture. Available online: https: //arteist.hr/trap-cajke-ili-gdje-mediteran-ljubi-cajke/ (accessed on 5 March 2020).

Ramnarine, Tina. 2007. Musical Performance in the Diaspora: Introduction. Ethnomusicology Forum 16: 1-17. [CrossRef]

Rašić, Miloš. 2018. Turbotronik: Studija slučaja Lenharta Tapesa i Mirjane Raić. Etno-Antropološki Problemi 13: 951-69. [CrossRef]

Reynolds, Simon. 2018. How Auto-Tune Revolutionized the Sound of Popular Music: An In-Depth History of the Most Important Pop Innovation of the Last 20 Years, from Cher's 'Believe' to Kanye West to Migos. Putchfork. Available online: https://pitchfork.com/features/article/how-auto-tune-revolutionized-the-soundof-popular-music/ (accessed on 5 March 2020).

Todorova, Maria. 1997. Imagining the Balkans. Oxford: Oxford University Press. 
Vidić Rasmussen, Ljerka. 2002. Newly Composed Folk Music of Yugoslavia. London and New York: Routledge.

Volčič, Zala. 2007. Yugo-Nostalgia: Cultural Memory and Media in Former Yugoslavia. Critical Studies in Media Communication 24: 21-38. [CrossRef]

Wang, Oliver. 2012. Beat-Making. Grove Music Online. Available online: https://doi.org/10.1093/gmo/9781561592630. article.A2218626 (accessed on 5 March 2020).

(c) (C) 2020 by the author. Licensee MDPI, Basel, Switzerland. This article is an open access article distributed under the terms and conditions of the Creative Commons Attribution (CC BY) license (http://creativecommons.org/licenses/by/4.0/). 